\title{
The mask as a pedagogical tool: from craft to scene
}

\author{
Everson G. Rodrigues, João P. M. Speckart* Larissa F. Blanco, Lucas Caparrós, Eduardo Okamoto
}

\begin{abstract}
The purpose of the project was to develop a interdisciplinary theatre pedagogy about masks, including maskmaking, neutral mask training and acting techniques based on Commedia dell'Arte aspects. To ground the methodology I have researched methods used by Jacques Lecoq, Amleto and Sartori and the theatre group Barracão Teatro, specially it's director Tiche Vianna. A group of young actors has been gathered to put in test the proposed trajectory and register objective and subjective material about the experience.
\end{abstract}

Key words:

Theatre, mask, theatre pedagogy.

\section{Introduction}

The project consisted on verifying the importance of learning techniques such as maskmaking craftsmanship, neutral mask training and expressive half-mask training in an actor's learning journey. To experiment this pedagogical proposition, a group of young actors has been gathered, including myself, to put in test some methods used and documented by the italian maskmakers Amleto and Donato Sartori, the french theatre pedagogue Jacques Lecoq and the brazilian theatre group Barracão Teatro, particularly its director, Tiche Vianna.

\section{Results and Discussion}

The experimental group, composed of students of the first year of the UNICAMP Performing Arts course and me, went with its work throughout all of the project's length. My method was based on courses I took in Barracão, workshops and classes I attended to. The experiment has been divided in two phases. The first one focused on physical training and exercises wearing neutral masks, such as "waving goodbye at the pier" and the "elemental journey" described by Lecoq", in order to improve body expression consciousness, and techniques and principles documented by Vianna ${ }^{2}$. It was also moment of shaping in clay masks we were going to wear during the next phase, using the chart method by Sartori ${ }^{3}$.

The second phase was the turn of expressive half-masks, beginning with the most representative ones from Commedia dell'Arte. We started studying their spinal axis and desires that drives their actions, then tried some lazzi and improvised scenes. As soon as our own masks became ready, we started improvising short scenes and relationships between. Our participation in the Ciência na Rua event in May was a very important discovery of how people on the streets were affected by our masks and vice-versa.

We put together a canovaccio based on our work so far and showed it to Vianna. In dialogue with her, she showed a series of inconsistencies in our work and we agreed we still had a lot to learn in both maskmaking and acting techniques. Time was running out, so we put end in experimentation, even though we desired to remake the masks and create new stories.

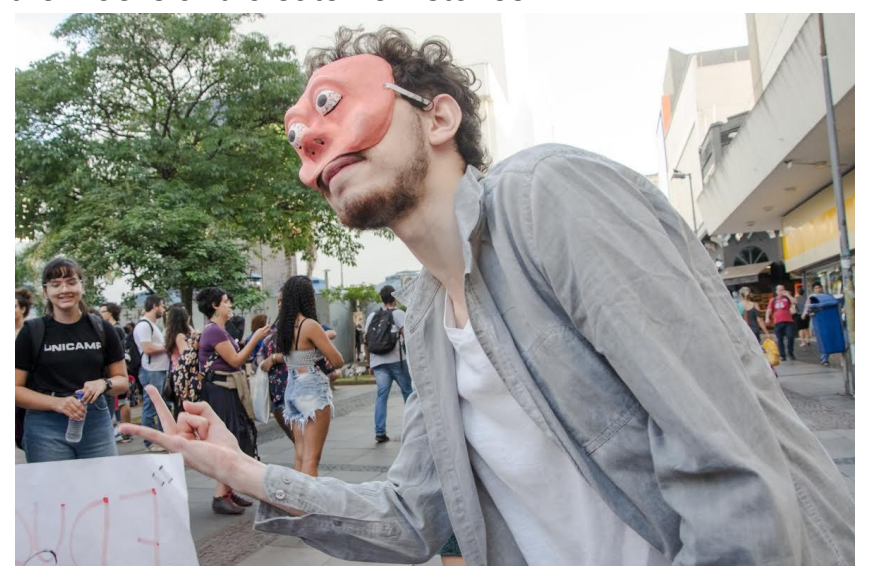

Image 1. Lucas Caparrós wearing his mask "Serginho" in our open experiment. Photograph by Dalton Yatabe.

\section{Conclusions}

The experiment changed artistic views and creative methods as expanded technical repertoire and vocabulary, even though it deserved more time. A cunning eye is needed when experimenting with new masks, since all of them are going to have distinct possibilities, so one should be always open to the unpredictable. The object's appearance plus the effect on its wearer results in an ensemble that should not be idealized or rationally anticipated. There must be separation of the two creative moments, or else expectations leak into acting and feel transplanted.

Masks evoke their own world of possibilities, being their very own dramaturgy. Remaking is an important aspect of this craft and can be related to theatre itself. Everything could be done again with more depth.

\section{Acknowledgement}

I thank my advisors E. Okamoto and T. Vianna by lending me their artistic views and letting us use their respective work spaces, SIM Cultura and Barracão Teatro. I also thank all the actors that helped me by being part of the experiment, it could not have happened without them.

\footnotetext{
${ }^{1}$ LECOQ, J. O corpo poético : uma pedagogia da criação teatral. São Paulo: Editora Senac São Paulo: Edições SESC SP, 2010

${ }^{2}$ CARDOSO in BELTRAME, V. N. \& ANDRADE, M. Teatro de Máscaras Florianópolis: UDESC, 2010. Pages 189-208.

${ }^{3}$ VIANNA, T. Para além da commedia dell'arte - a máscara e sua pedagogia. Campinas, SP : Unicamp, 2017.
} 